\title{
Desulfovibrio piezophilus sp. nov., a piezophilic, sulfate-reducing bacterium isolated from wood falls in the Mediterranean Sea
}

Correspondence

Bernard Ollivier

bernard.ollivier@univmed.fr
Saber Khelaifia, ${ }^{1}$ Marie-Laure Fardeau, ${ }^{1}$ Nathalie Pradel, ${ }^{1}$
Clément Aussignargues, ${ }^{1}$ Marc Garel, ${ }^{2}$ Christian Tamburini,
Jean-Luc Cayol, ${ }^{1}$ Sylvie Gaudron, ${ }^{3}$ Françoise Gaill ${ }^{3}$ and Bernard Ollivier ${ }^{1}$

${ }^{1}$ IRD, UMR 180, IFR-BAIM, Universités de Provence et de la Méditerranée, ESIL Case 925, 163 Avenue de Luminy, F-13288 Marseille cedex 9, France

${ }^{2}$ Université de la Méditerranée, Centre d'Océanologie de Marseille, LMGEM UMR 6117 CNRS INSU, Campus de Luminy, Case 901, 163 Avenue de Luminy, 13288 Marseille cedex 9, France

${ }^{3}$ Université Pierre et Marie Curie - Paris VI, CNRS, UMR 7138, Systématique, Adaptation, Evolution, AMEX, 7 Quai St Bernard, 75252 Paris, France

\begin{abstract}
A novel sulfate-reducing bacterium, designated $\mathrm{C} 1 \mathrm{TLV}^{\circ} \mathrm{O}^{\top}$, was isolated from wood falls at a depth of $1693 \mathrm{~m}$ in the Mediterranean Sea. Cells were motile vibrios $(2-4 \times 0.5 \mu \mathrm{m})$. Strain C1TLV $30^{\top}$ grew at temperatures between 15 and $45^{\circ} \mathrm{C}$ (optimum $30{ }^{\circ} \mathrm{C}$ ) and at $\mathrm{pH} 5.4-8.6$ (optimum 7.3). It required $\mathrm{NaCl}$ for growth (optimum at $25 \mathrm{~g} \mathrm{NaCl} \mathrm{I}^{-1}$ ) and tolerated up to $80 \mathrm{~g}$ $\mathrm{NaCl} \mathrm{I}{ }^{-1}$. Strain $\mathrm{C} 1 \mathrm{TLV} \mathrm{O}^{\top}$ used as energy sources: lactate, fumarate, formate, malate, pyruvate and ethanol. The end products from lactate oxidation were acetate, $\mathrm{H}_{2} \mathrm{~S}$ and $\mathrm{CO}_{2}$ in the presence of sulfate as terminal electron acceptor. Besides sulfate, thiosulfate and sulfite were also used as terminal electron acceptors, but not elemental sulfur, fumarate, nitrate or nitrite. Strain C1TLV30 ${ }^{\top}$ possessed desulfoviridin and was piezophilic, growing optimally at $10 \mathrm{MPa}$ (range $0-30 \mathrm{MPa}$ ). The membrane lipid composition of this strain was examined to reveal an increase in fatty acid chain lengths at high hydrostatic pressures. The $\mathrm{G}+\mathrm{C}$ content of the genomic DNA was $49.6 \%$ and the genome size was estimated at $3.5 \pm 0.5 \mathrm{Mb}$. Phylogenetic analysis of the SSU rRNA gene sequence indicated that strain $\mathrm{C} 1 \mathrm{TLV} 30^{\top}$ was affiliated to the genus Desulfovibrio with Desulfovibrio profundus being its closest phylogenetic relative (similarity of $96.4 \%$ ). On the basis of SSU rRNA gene sequence comparisons and physiological characteristics, strain C1TLV30 ${ }^{\top}$ $\left(=\mathrm{DSM} 21447^{\top}=\mathrm{JCM} 1548^{\top}\right)$ is proposed to be assigned to a novel species of the genus Desulfovibrio, Desulfovibrio piezophilus sp. nov.
\end{abstract}

Sulfate-reducing bacteria (SRB) are universally distributed in marine sediments where sulfate reduction is the dominant anaerobic biomineralization pathway (up to $50 \%$ of organic matter) (Fauque \& Ollivier, 2004). They constitute a group of prokaryotes unified by the capability to perform dissimilatory sulfate reduction to sulfide as a major component of their bioenergetics processes. They are known to inhabit deep marine or terrestrial environments such as oil reservoirs, aquifers, groundwaters and hydrothermal vents, where their geomicrobiological significance has often been underlined (Ollivier et al., 2007; Parkes \&

Abbreviations: FA, fatty acid; SRB, sulfate-reducing bacteria.

The GenBank/EMBL/DDBJ accession number for the 16S rRNA gene sequence of strain $\mathrm{C} 1 \mathrm{TLV}^{\mathrm{T}} \mathrm{T}^{\top}$ is $\mathrm{HM} 852532$.

Two supplementary figures are available with the online version of this paper.
Sass, 2007; Ollivier \& Guyot, 2009). In deep-sea environments, most thermophilic to hyperthermophilic SRB pertaining to the domains Bacteria (e.g. Thermodesulfatator spp.) or Archaea (e.g. Archaeoglobus spp.) - have been isolated from hydrothermal vents where, besides high temperatures, they have to face other drastic physicochemical conditions such as the presence of toxic chemical compounds and high pressures (Ollivier et al., 2007). From the cooler parts of these extreme environments, a moderately thermophilic SRB growing optimally at $45{ }^{\circ} \mathrm{C}$, Desulfonauticus submarinus (Audiffrin et al., 2003), and a mesophilic one, Desulfovibrio hydrothermalis (Alazard et al., 2003), growing optimally at $35{ }^{\circ} \mathrm{C}$ have been recovered. Similarly, Desulfovibrio profundus was enriched and isolated from deep sediment layers in the Japan Sea (Bale et al., 1997). However, there are few reports on the growth response of these sulfate-reducers to hydrostatic pressure. 
Desulfovibrio profundus was the first SRB ascribed as growing at up to $40 \mathrm{Mpa}$, with optimum activities occurring between 10 and $15 \mathrm{MPa}$. Thereafter, Desulfovibrio hydrothermalis was shown to grow faster at $26 \mathrm{MPa}$ (the pressure in the environment from where it was extracted) than at atmospheric pressure $(0.1 \mathrm{MPa})$, thus demonstrating its piezophilic characteristic.

In this study, we report on the isolation of strain C1TLV $30^{\mathrm{T}}$ from wood falls at a depth of $1693 \mathrm{~m}$ in the Mediterranean Sea, which grows optimally at $10 \mathrm{MPa}$ and shows unique changes in membrane lipid composition. The phylogenetic and physiological characteristics of this strain suggest it as representing a novel species, for which we propose the name Desulfovibrio piezophilus sp. nov.

Strain C1TLV30 ${ }^{\mathrm{T}}$ was isolated from wood falls consisting of natural Douglas fir wood cubes $(2 \times 2 \times 2 \mathrm{~cm})$ placed for one year on deep-sea sediments in a colonization device named CHEMECOLI (Gaudron et al., 2010). One device could harbour roughly 100 cubes. The CHEMECOLI (M70/ 2b_833_TRAC-13) was deployed at the cold seep site 'Central Zone 2A' in the Pockmark area in the Nile DeepSea Fan in the eastern Mediterranean (32 $31^{\prime} 97^{\prime \prime} \mathrm{N} 30^{\circ} 21^{\prime}$ $18^{\prime \prime} \mathrm{E}, 1693 \mathrm{~m}$ deep, in situ temperature: $14{ }^{\circ} \mathrm{C}$ ) on 18 November 2006 during the BIONIL cruise (RV Meteor M70/ $2 b$ ) by the ROV (Remotely Operated Vehicle) Quest 4000 (Marum, Bremen, Germany) and recovered by the ROV Victor 6000 (Ifremer, Toulouse, France) on 10 November 2007 during the MEDECO-2 cruise (RV Pourquoi Pas ?). All metadata are stored in the PANGAEA database (http://www. pangaea.de) and PANGAEA event labels for the experiments are cited accordingly. For deployment and recovery, a hermetic box was used with separate compartments for each device, to avoid washing and mixing. On board, some randomly selected wood cubes issued from a CHEMECOLI were stored anaerobically and frozen at $-20{ }^{\circ} \mathrm{C}$ in $10 \%$ glycerol until isolation of SRB.

Basal medium (BM) contained (per litre of distilled water): $0.3 \mathrm{~g} \mathrm{KH}_{2} \mathrm{PO}_{4}, 0.3 \mathrm{~g} \mathrm{~K}_{2} \mathrm{HPO}_{4}, 1 \mathrm{~g} \mathrm{NH}_{4} \mathrm{Cl}, 25 \mathrm{~g} \mathrm{NaCl}, 4.0 \mathrm{~g}$ sodium sulfate, $0.1 \mathrm{~g} \mathrm{KCl}, \quad 0.1 \mathrm{~g} \quad \mathrm{CaCl}_{2} \cdot 2 \mathrm{H}_{2} \mathrm{O}, \quad 3 \mathrm{~g}$ $\mathrm{MgCl}_{2} \cdot 6 \mathrm{H}_{2} \mathrm{O}, 0.5 \mathrm{~g}$ cysteine hydrochloride, $0.1 \mathrm{~g}$ yeast extract (Difco), $10 \mathrm{ml}$ trace element solution (Widdel \& Pfenning, 1984) and $1 \mathrm{ml} 0.1 \%$ resazurin. The $\mathrm{pH}$ was adjusted to 7.0 with $10 \mathrm{M} \mathrm{KOH}$ solution at atmospheric pressure and the medium was prepared anaerobically as previously described (Fardeau et al., 1997). Prior to culture inoculation with pieces of wood falls (around $1 \mathrm{~g}$ ), $0.1 \mathrm{ml}$ $10 \%(\mathrm{w} / \mathrm{v}) \mathrm{NaHCO}_{3}$ and $0.1 \mathrm{ml} 2 \%(\mathrm{w} / \mathrm{v}) \mathrm{Na}_{2} \mathrm{~S} .9 \mathrm{H}_{2} \mathrm{O}$ and $20 \mathrm{mM}$ lactate as energy source were injected from sterile stock solutions into the tubes for enrichment and isolation. The Hungate technique (Hungate, 1969) was used throughout this study and pure cultures were obtained as reported by Alazard et al. (2003).

Morphological characteristics and purity were observed with an Optiphot (Nikon) phase-contrast microscope. For transmission electron microscopy studies, cell preparations were negatively stained with sodium phosphotungstate, as previously described (Fardeau et al., 1997). Growth experiments were performed at atmospheric pressure in duplicate, using Hungate tubes containing basal medium and different electron donors at $20 \mathrm{mM}$ (lactate, fumarate, formate, malate, pyruvate, ethanol, acetate, propionate, butyrate, succinate, fructose, Casamino-acids, benzoate, phenol) and hydrogen at 2 bars. Elemental sulfur ( $1 \%$, $\mathrm{w} / \mathrm{v})$, sulfate $(20 \mathrm{mM})$, thiosulfate $(20 \mathrm{mM})$, sulfite $(2 \mathrm{mM})$, fumarate $(20 \mathrm{mM})$, nitrate $(10 \mathrm{mM})$ and nitrite $(2 \mathrm{mM})$ were tested as terminal electron acceptors. The $\mathrm{pH}$, temperature and $\mathrm{NaCl}$ concentration ranges for growth were determined using basal medium supplemented with $20 \mathrm{mM}$ lactate as electron donor at atmospheric pressure. Temperatures for growth were tested between 10 and $50{ }^{\circ} \mathrm{C}$. $\mathrm{H}_{2} \mathrm{~S}$ production was determined using the method of CordRuwisch (1985). The presence of spores was checked as described by Fardeau et al. (1997). End products of metabolism and bacterial growth were measured as described by the same authors (Fardeau et al., 1997).

For growth experiments under hydrostatic pressure, completely filled Hungate tubes $(18 \mathrm{ml})$ containing $\mathrm{BM}$ were inoculated in triplicate and incubated at $30{ }^{\circ} \mathrm{C}$ under anaerobic conditions. Incubations under high-pressure were performed using pressure vessels. The screwed top end-cap was connected, via a stainless steel tube, to the piloted pressure generator (Tamburini et al., 2009) allowing a linear increase of the hydrostatic pressure $\left(0.5 \mathrm{MPa} \mathrm{sec}{ }^{-1}\right)$ by the programmable computer-driven system of the piloted pressure generator. The software Metrolog (MetroMesures, Mennecy, France) allows an increase (or decrease) in the range of hydrostatic pressure with precise regulation $(0.2 \%)$; it also allows constant or variable flow injection so that the volume injected can be measured precisely. The working pressure was up to $40 \mathrm{MPa}$. Hungate tubes were placed three per pressure vessel. Optical density $\left(\mathrm{OD}_{580}\right)$ was measured regularly over 4 days.

To study cellular fatty acid composition, strain C1TLV30 ${ }^{\mathrm{T}}$ was grown as preculture to an optical density of 0.2 at $600 \mathrm{~nm}$ under atmospheric pressure $(0.1 \mathrm{MPa})$. Then, $1 / 100$ of the preculture was inoculated in fresh medium and grown under atmospheric pressure or under high hydrostatic pressure (10 MPa or $25 \mathrm{MPa}$ ) for $40 \mathrm{~h}$ at $30{ }^{\circ} \mathrm{C}$ under anoxic conditions. A second round of growth was performed under the same conditions, from $1 / 100$ of the first round cultures. Cells obtained from the first and second rounds were used for comparative lipid composition analysis. Cultures of $40 \mathrm{ml}$ from both conditions (atmospheric and $10 \mathrm{MPa}$ - or $25 \mathrm{MPa}-$ exposed cultures) were harvested by centrifugation at $6000 \mathrm{~g}$ for 20 min at $4{ }^{\circ} \mathrm{C}$ and then pellets were stored at $-20{ }^{\circ} \mathrm{C}$. Fatty acid composition from these pellets was determined at the Deutsche Sammlung von Mikroorganismen und Zellkulturen (DSMZ), Braunschweig, Germany, in accordance with the procedure of Vainshtein et al. (1992). Results are means of three independent experiments.

For pulsed-field gel electrophoresis, preparation of DNA plugs, digestions, electrophoresis conditions and pattern 
analyses were performed according to Lefèvre et al. (2009). Restriction enzymes (PacI, NotI, I-CeuI, XbaI, PstI and DraI) were used according to the manufacturer's instructions (New England Biolabs). Molecular masses of all fragments produced by $\mathrm{Pacl}$ restriction endonuclease digestion of genomic DNA were calculated as the mean from three pulsed-field gels. Plasmids were prepared by the alkaline lysis method described by Kado \& Liu (1981).

The $\mathrm{G}+\mathrm{C}$ content of DNA was determined at the DSMZ. The DNA was isolated and purified by chromatography on hydroxyapatite and the $\mathrm{G}+\mathrm{C}$ content was determined by HPLC as described by Mesbah et al. (1989).

Methods for purification of the DNA, PCR amplification and sequencing of the 16S rRNA gene were as described by Cashion et al. (1977) and Hernandez-Eugenio et al. (2000). The partial sequences generated were assembled using BioEdit v. 5.0.9. (Hall, 1999) and the consensus sequence of 1539 nt was corrected manually for errors. The most closely related sequences in GenBank (version 178) (Benson et al., 2008) and the Ribosomal Database Project (release 10), identified using BLAST (Altschul et al., 1997) and the Sequence Match program (Cole et al., 2009), were extracted and aligned. The consensus sequence was then manually adjusted to conform to the 16S rRNA secondary structure model (Winker \& Woese, 1991). Nucleotide ambiguities were omitted and evolutionary distances were calculated using the Jukes and Cantor option (Jukes \& Cantor, 1969). Dendrograms were reconstructed with the TREECON program using the neighbour-joining method (Saitou \& Nei, 1987). Tree topology was re-examined by the bootstrap method (1000 replications) of resampling (Felsenstein, 1985). The topology was also supported using the maximum-parsimony and maximum-likelihood algorithms.

Enrichments in the medium containing lactate as electron donor and sulfate as electron acceptor and inoculated with pieces of wood falls (around $1 \mathrm{~g}$ ) were positive after one week of incubation at $30^{\circ} \mathrm{C}$. Thereafter, colonies of SRB developed in roll-tubes after 15 days of incubation at the same temperature. They were picked separately and the process of serial dilution was repeated until the isolates were deemed to be axenic. Several strains similar in morphology (vibrio-like micro-organisms) and phylogeny (sequence similarities ranging from 99 to $100 \%$ ) and incompletely oxidizing lactate to acetate were isolated. One of these strains, designated C1TLV $30^{\mathrm{T}}$, was selected and used for further characterization.

Cells stained Gram-negative. They were motile, non-sporeforming vibrios (2 to $4 \mu \mathrm{m}$ in length and $0.5 \mu \mathrm{m}$ in diameter), and generally occurred singly or in pairs (data not shown). Strain C1TLV $30^{\mathrm{T}}$ was mesophilic and grew at temperatures ranging from 15 to $45{ }^{\circ} \mathrm{C}$, with an optimum at $30{ }^{\circ} \mathrm{C}$. The isolate required $\mathrm{NaCl}$ for growth (optimum $25 \mathrm{~g} \mathrm{l}^{-1}$ ), and tolerated up to $80 \mathrm{~g} \mathrm{NaCl}^{-1}$. The optimum $\mathrm{pH}$ for growth was 7.3 (range between $\mathrm{pH} 5.4$ and 8.6). Strain C1TLV30 ${ }^{\mathrm{T}}$ grew optimally at $10 \mathrm{MPa}$ (range 0 $30 \mathrm{MPa}$ ) (Supplementary Fig. S1, available in IJSEM
Online). Under optimal growth conditions, doubling time was estimated to be around $10 \mathrm{~h}$. Sulfate, thiosulfate and sulfite were utilized as electron acceptors, but not elemental sulfur, fumarate, nitrate or nitrite. When using sulfate as terminal electron acceptor, strain $\mathrm{C} 1 \mathrm{TLV} 30^{\mathrm{T}}$ grew on lactate, fumarate, formate, malate, pyruvate, ethanol and hydrogen. Hydrogen was only used in the presence of acetate as carbon source. Pyruvate and fumarate were fermented. No growth was observed on the following substrates: acetate, propionate, butyrate, succinate, fructose, Casamino-acids, benzoate or phenol. The end products from lactate oxidation were acetate, $\mathrm{CO}_{2}$ and $\mathrm{H}_{2} \mathrm{~S}$ in the presence of sulfate as terminal electron acceptor.

SRB are widely distributed in nature with a peculiar emphasis in marine ecosystems (Fauque \& Ollivier, 2004). They are known to inhabit extreme environments submitted to several hundred bars of pressure such as deep-sea hydrothermal vents, oil reservoirs and other subterrestrial ecosystems (Ollivier et al., 2007; Parkes \& Sass, 2007), thus suggesting that they have to cope with high hydrostatic pressure within these habitats. Only a few reports deal with the growth responses of SRB to high hydrostatic pressures. They include two species of the genus Desulfovibrio, Desulfovibrio hydrothermalis and Desulfovibrio profundus, which have been isolated from hydrothermal vents in the Pacific Ocean (Alazard et al., 2003) and deep sediment layers in the Japan Sea (Bale et al., 1997), respectively. Here we report the isolation of a novel SRB (strain C1TLV30 ${ }^{\mathrm{T}}$ ) from wood falls located at a depth of $1693 \mathrm{~m}$ in the Mediterranean Sea which has Desulfovibrio profundus as its closest phylogenetic relative ( $96.4 \%$ similarity) (Fig. 1). It grew optimally at $10 \mathrm{MPa}$ and tolerated hydrostatic pressures up to 25-30 Mpa, thus demonstrating its piezophilic nature (Supplementary Fig. S1). However, in contrast to Desulfovibrio profundus, strain C1TLV $30^{\mathrm{T}}$ was not active at hydrostatic pressures up to about $40 \mathrm{MPa}$, with the upper limit of pressure for growth being $30 \mathrm{MPa}$. In the case of Desulfovibrio hydrothermalis, the optimum pressure for growth was not reported, but this bacterium grew faster at $26 \mathrm{Mpa}$, corresponding to the pressure at the depth from which it was isolated $(2600 \mathrm{~m})$, than at $0.1 \mathrm{MPa}$. This is also true for strain C1TLV30 ${ }^{\mathrm{T}}$ (better growth at $17 \mathrm{MPa}$ than at $0.1 \mathrm{MPa}$ ), thus demonstrating that these species of the genus Desulfovibrio together with Desulfovibrio profundus are well adapted to deep-sea environments.

The genome of strain $\operatorname{C1TLV} 30^{\mathrm{T}}$ was characterized by PFGE analysis. The overall DNA G $+C$ content of strain C1TLV30 ${ }^{\mathrm{T}}$ was $49.6 \mathrm{~mol} \%$. We used several restriction endonucleases to cleave strain C1TLV $30^{\mathrm{T}}$ genomic DNA into a reasonable number of fragments. As shown in Supplementary Figure S2, PacI generated a manageable number of fragments that were relatively easily resolvable by PFGE. Analysis of the digestion pattern using QUANTITY ONE quantification software (Bio-Rad) indicated that the genome size of strain C1TLV $30^{\mathrm{T}}$ was about $3.5 \pm 0.5 \mathrm{Mb}$. The density of the band around $800 \mathrm{bp}$ was 


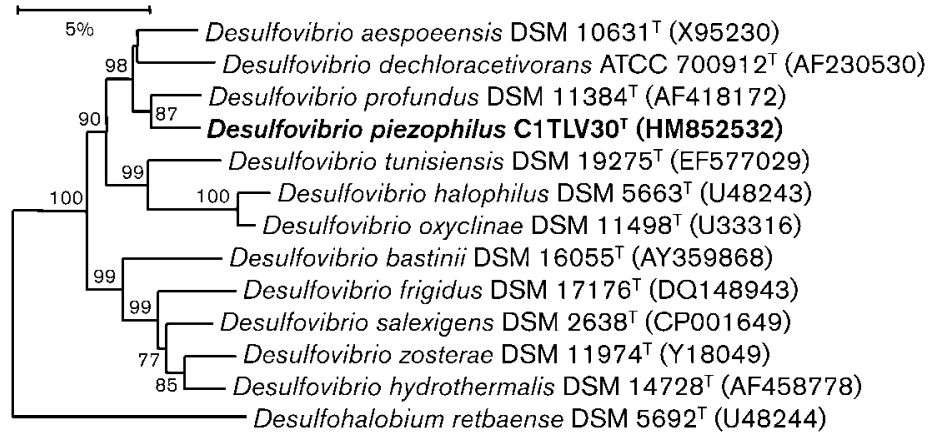

Fig. 1. Phylogenetic tree based on $16 \mathrm{~S}$ rRNA gene sequence data indicating the position of strain $\mathrm{C}_{1 \mathrm{TLV}} 30^{\top}$ amongst members of the genus Desulfovibrio and related bacteria. Accession numbers are shown in parentheses. Bar, 5 substitutions per 100 nucleotides.

clearer than those of bands with lower molecular sizes, suggesting a randomly linearized fragment. Hence it was not considered here. No plasmid was revealed using the Kado and Liu method for plasmid extraction (data not shown; Kado \& Liu, 1981).

A major characteristic of piezophilic micro-organisms seems to reside in membrane fatty acid (FA) composition. For example, increases in the levels of lower-meltingtemperature branched or unsaturated FAs in piezophilic bacteria have been reported to increase membrane fluidity (Kates, 1986; Yano et al., 1998). The FA composition of total lipids from strain C1TLV30 ${ }^{\mathrm{T}}$, grown at $30{ }^{\circ} \mathrm{C}$ and 0.1 , 10 or $25 \mathrm{Mpa}$, indicated that the major FAs of the strain were $C_{15: 0}, C_{16: 0}, C_{16: 1}, C_{17: 0}, C_{17: 1}, C_{18: 0}$ and $C_{18: 1}$. Relative changes in the proportions of these seven major types of FA after exposure to hydrostatic pressuredependent growth conditions are shown in Table 1. Total branched FAs were between 59 and $68 \%$, whatever the growth conditions. Total mono-unsaturated FAs were $24 \%$ after growth during $35 \mathrm{~h}$ under atmospheric pressure $(0.1 \mathrm{MPa})$ but were 42 and $35 \%$ when growth was performed at 10 or $25 \mathrm{MPa}$, respectively. After two rounds of growth at $0.1,10$ or $25 \mathrm{MPa}$, mono-unsaturated FAs were $30,31.5$ and $40 \%$, respectively. Thus, no evident correlation was made between the levels of branched or unsaturated FAs and hydrostatic pressure for strain C1TLV30 ${ }^{\mathrm{T}}$. Interestingly, regarding chain length, the proportion of $\mathrm{C}_{15}$ and $\mathrm{C}_{16}$ FAs was $62 \%$ at $0.1 \mathrm{MPa}$, and $46-48 \%$ at 10 and $25 \mathrm{MPa}$ after the first round of growth. It was 58, 52.5 and $38.5 \%$, respectively, after the second round. Thus, Desulfovibrio piezophilus sp. nov. could exhibit a novel mechanism in which an overall increase in the level of FA chain length, both saturated and monounsaturated, branched or not, would occur during hydrostatic pressure increase.

Although increases in only unsaturated FAs were reported to be involved in hydrostatic pressure adaptation in microorganisms such as species of the genus Shewanella and

Table 1. Fatty acid composition of strain $\mathrm{C} 1 \mathrm{TLV} 30^{\top}$ grown at $30{ }^{\circ} \mathrm{C}$ under different hydrostatic pressure conditions

Values are means $(n=3)$. FAs comprising less than $0.5 \%$ of the sample are not included. b, Branched fatty acid.

\begin{tabular}{|c|c|c|c|c|c|c|}
\hline \multirow[t]{2}{*}{ Fatty acid type } & \multicolumn{6}{|c|}{ Total fatty acids (\%) at indicated pressure } \\
\hline & \multicolumn{3}{|c|}{ Round 1} & \multicolumn{3}{|c|}{ Round 2} \\
\hline $15: 0 \mathrm{~b}$ & 22 & 21 & 30 & 18.5 & 29 & 31 \\
\hline $16: 0$ & 12 & 13.5 & 21 & 9 & 17 & 17 \\
\hline $17: 0$ & - & 1 & 1 & 2 & 0.5 & 1 \\
\hline $17: 0 b$ & 8 & 10 & 8 & 9 & 11.5 & 9 \\
\hline $17: 1 b$ & 14 & 17.5 & 10 & 17 & 19 & 16 \\
\hline $18: 0$ & 17 & 5 & 8.5 & 14.5 & 8.5 & 8 \\
\hline $18: 0 b$ & 1 & - & 1 & 2 & - & 1 \\
\hline Total $\mathrm{C}_{15}+\mathrm{C}_{16}$ FAs & 46 & 48 & 62 & 38.5 & 52.5 & 58 \\
\hline
\end{tabular}


Photobacterium profundum (Allen et al., 1999; Bartlett, 2002; Simonato et al., 2006), it is the combined ratio of different FAs that determines the viscosity of the membranes. In strain $\mathrm{C} 1 \mathrm{TLV} 30^{\mathrm{T}}$, increase in FA chain length may be the major bacterial response in the establishment of optimal membrane fluidity. Thus, strain $\operatorname{C} 1 \mathrm{TLV} 30^{\mathrm{T}}$ could present new particularities in FA metabolism linked to hydrostatic pressure changes that have not been reported for piezophilic species of the genus Desulfovibrio so far. In this respect, this strain provides a particularly good model for understanding adaptation of members of the genus Desulfovibrio to the deep ocean.

To our knowledge, the greatest depth in a marine environment at which a sulfate reducer was isolated has so far not exceeded $3000 \mathrm{~m}$, corresponding to in situ pressure of $30 \mathrm{MPa}$. It is therefore a challenge for microbiologists to cultivate SRB from depths around and below $3000 \mathrm{~m}$ in marine ecosystems to determine if they are of geomicrobiological relevance in oxidizing organic matter in abysses, due to their hydrogenotrophic metabolism in particular. This is probably the case for strain C1TLV30 ${ }^{\mathrm{T}}$, which should contribute to degradation of cellulose and hemicellulose contained in wood falls by oxidizing $\mathrm{H}_{2}$ delivered by fermentative micro-organisms.

However, at this stage, few microbiological studies regarding wood falls have been undertaken (Nilsson \& Björdal, 2008; Palacios et al., 2009). Further experiments are needed to clarify the microbial community interactions existing within these deep-sea ecosystems.

Besides phylogenetic differences observed between Desulfovibrio profundus and strain C1TLV30 ${ }^{\mathrm{T}}$, several phenotypic and genetic characteristics allowed us to distinguish them. They include the temperature range for growth as Desulfovibrio profundus and strain C1TLV $30^{\mathrm{T}}$ should be considered as thermophilic and mesophilic, respectively (Table 2). Moreover, unlike Desulfovibrio profundus, strain C1TLV $30^{\mathrm{T}}$ used ethanol and formate as electron donors but not nitrate as terminal electron acceptor, and did not ferment lactate (Table 1). Desulfovibrio profundus also differed from strain C1TLV $30^{\mathrm{T}}$ by having a higher $\mathrm{G}+\mathrm{C}$ content of the DNA (Table 2). Therefore, based on phylogenetic, genetic, phenotypic and chemotaxonomic characteristics of strain C1TLV30 ${ }^{\mathrm{T}}$, we propose that this strain be assigned to a novel species of the genus Desulfovibrio, Desulfovibrio piezophilus sp. nov.

\section{Description of Desulfovibrio piezophilus sp. nov.}

Desulfovibrio piezophilus [pi.e.zo.phi'lus. Gr. v. piezo to press; N.L. adj. philus - $a-u m$ (from Gr. adj. philos $-\hat{e}-o n$ ) loving; N.L. masc. adj. piezophilus loving pressure].

Cells are strictly anaerobic, Gram-stain-negative, motile, nonspore-forming vibrios, approximately 2 to $4 \mu \mathrm{m}$ in length and about $0.5 \mu \mathrm{m}$ in diameter. They generally occur singly or in pairs. The temperature range for growth is 15 to $45{ }^{\circ} \mathrm{C}$ (optimum $30{ }^{\circ} \mathrm{C}$ ). The optimum $\mathrm{NaCl}$ concentration for growth is $2.5 \%$ (range $0.1-8 \%$ ). The optimum $\mathrm{pH}$ is 7.3 .
Table 2. Comparison of physiological and metabolic properties between strain $\mathrm{C}_{1 \mathrm{TLV}} \mathrm{O}^{\top}$ and Desulfovibrio profundus

Strains: 1, C1TLV30 ${ }^{\mathrm{T}}$; 2, D. profundus (data from Bale et al., 1997). + , Used; -, not used.

\begin{tabular}{|lcc|}
\hline Characteristic & $\mathbf{1}$ & $\mathbf{2}$ \\
\hline Temperature range $\left({ }^{\circ} \mathrm{C}\right)$ & $15-45$ & $15-65$ \\
Optimum temperature $\left({ }^{\circ} \mathrm{C}\right)$ & 30 & 25 \\
$\mathrm{pH}$ range & $5.4-8.6$ & $4.5-9$ \\
Optimum pH & 7.3 & 7 \\
NaCl range $(\%)$ & $0.1-8.0$ & $0.2-10$ \\
Optimum NaCl $(\%)$ & 2.5 & $0.6-10$ \\
DNA G+C content $(\mathrm{mol} \%)$ & 49.6 & 53.0 \\
Substrate utilization & & \\
$\quad$ Ethanol & + & - \\
$\quad$ Malate & + & - \\
$\quad$ Formate & + & - \\
$\quad$ Fumarate & + & - \\
Lactate fermentation & - & + \\
Nitrate as electron acceptor & - & + \\
\hline
\end{tabular}

Grows optimally at $10 \mathrm{MPa}$. Upper limit of hydrostatic pressure for growth is $25-30 \mathrm{MPa}$. Uses lactate, fumarate, formate, malate, pyruvate, ethanol, and hydrogen. Hydrogen is only used in the presence of acetate as carbon source. Ferments pyruvate and fumarate. Substrates not used are: acetate, propionate, butyrate, succinate, fructose, Casamino acids, benzoate or phenol. Incompletely oxidizes its substrates to acetate, $\mathrm{CO}_{2}$ and $\mathrm{H}_{2} \mathrm{~S}$ in the presence of sulfate. Besides sulfate, thiosulfate and sulfite are also used as terminal electron acceptors, but not elemental sulfur, fumarate, nitrate or nitrite. At $10 \mathrm{MPa}$, the strain appears to exhibit an increase in FA chain lengths. The $\mathrm{G}+\mathrm{C}$ content of DNA of the type strain is $49.6 \mathrm{~mol} \%$ and the genome size is $3.5 \pm 0.5 \mathrm{Mb}$.

The type strain is $\mathrm{C}_{\mathrm{T}} \mathrm{TLV} 30^{\mathrm{T}}\left(=\mathrm{DSM} 21447^{\mathrm{T}}=\mathrm{JCM}\right.$ $15486^{\mathrm{T}}$ ) isolated from wood falls at a depth of $1693 \mathrm{~m}$ in the Mediterranean Sea.

\section{Acknowledgements}

The authors would like to thank Sébastien Duperron who has deployed and recovered the CHEMECOLI that contained the wood cubes. We are grateful to Antje Boetius and Catherine Pierre, chief scientists, respectively, of the BIONIL and MEDECO-2 cruises, and the captains and crews of the RV Meteor $(M 70 / 2 b)$ and the RV Pourquoi pas?, and the teams operating the ROV Quest 4000 (Marum, Bremen, Germany) and ROV Victor 6000 (Ifremer, Toulouse, France). Sample collection was funded by CHEMECO (European Sciences Foundation/Eurocores/EURODEEP), GDRE DIWOOD (European Research Group CNRS-MPG) and HERMES (EC). We thank Sabine Leroy for help in PFGE analysis and Alain Dolla for help in fatty acid analysis. We thank Dr P. Roger for revising the manuscript.

\section{References}

Alazard, D., Dukan, S., Urios, A., Verhé, F., Bouabida, N., Morel, F., Thomas, P., Garcia, J. L. \& Ollivier, B. (2003). Desulfovibrio 
hydrothermalis sp. nov., a novel sulfate-reducing bacterium isolated from hydrothermal vents. Int J Syst Evol Microbiol 53, 173-178.

Allen, E. E., Facciotti, D. \& Bartlett, D. H. (1999). Monounsaturated but not polyunsaturated fatty acids are required for growth of the deep-sea bacterium Photobacterium profundum SS9 at high pressure and low temperature. Appl Environ Microbiol 65, 1710-1720.

Altschul, S. F., Madden, T. L., Schäffer, A. A., Zhang, J., Zhang, Z., Miller, W. \& Lipman, D. J. (1997). Gapped BLAST and PSI-BLAST: a new generation of protein database search programs. Nucleic Acids Res 25, 3389-3402.

Audiffrin, C., Cayol, J. L., Joulian, C., Casalot, L., Thomas, P., Garcia, J. L. \& Ollivier, B. (2003). Desulfonauticus submarinus gen. nov., sp. nov., a novel sulfate-reducing bacterium isolated from a deep-sea hydrothermal vent. Int J Syst Evol Microbiol 53, 1585-1590.

Bale, S. J., Goodman, K., Rochelle, P. A., Marchesi, J. R., Fry, J. C., Weightman, A. J. \& Parkes, R. J. (1997). Desulfovibrio profundus sp. nov., a novel barophilic sulfate-reducing bacterium from deep sediment layers in the Japan Sea. Int J Syst Bacteriol 47, 515-521.

Bartlett, D. H. (2002). Pressure effects on in vivo microbial processes. Biochim Biophys Acta 1595, 367-381.

Benson, D. A., Karsch-Mizrachi, I., Lipman, D. J., Ostell, J. \& Wheeler, D. L. (2008). GenBank. Nucleic Acids Res 36 (Database issue, ), D25D30.

Cashion, P., Holder-Franklin, M. A., McCully, J. \& Franklin, M. (1977). A rapid method for the base ratio determination of bacterial DNA. Anal Biochem 81, 461-466.

Cole, J. R., Wang, Q., Cardenas, E., Fish, J., Chai, B., Farris, R. J., Kulam-Syed-Mohideen, A. S., McGarrell, D. M., Marsh, T. \& other authors (2009). The Ribosomal Database Project: improved alignments and new tools for rRNA analysis. Nucleic Acids Res 37 (Database issue), D141-D145.

Cord-Ruwisch, R. (1985). A quick method for the determination of dissolved and precipitated sulfides in cultures of sulfate-reducing bacteria. J Microbiol Methods 4, 33-36.

Fardeau, M. L., Ollivier, B., Patel, B. K. C., Magot, M., Thomas, P., Rimbault, A., Rocchiccioli, F. \& Garcia, J. L. (1997). Thermotoga hypogea sp. nov., a xylanolytic, thermophilic bacterium from an oilproducing well. Int J Syst Bacteriol 47, 1013-1019.

Fauque, G. \& Ollivier, B. (2004). Anaerobes: the sulfate-reducing bacteria as an example of metabolic diversity. In Microbial Diversity and Bioprospecting, pp. 169-176. Edited by A. T. Bull. Washington, DC: American Society for Microbiology.

Felsenstein, J. (1985). Confidence limits on phylogenies: an approach using the bootstrap. Evolution 39, 783-791.

Gaudron, S. M., Pailleret, M., Duperron, S., Pradillon, F. \& Gaill, F. (2010). Colonization of organic substrates deployed in deep-sea reducing habitats by symbiotic species and associated fauna. Mar Environ Res 70, 1-12.

Hall, T. A. (1999). BioEdit: a user-friendly biological sequence alignment editor and analysis program for Windows 95/98/NT Nucleic Acids Symp Ser 41, 95-98.

Hernandez-Eugenio, G., Fardeau, M. L., Patel, B. K. C., Marcarie, H., Garcia, J. L. \& Ollivier, B. (2000). Desulfovibrio mexicanus sp. nov., a sulfate-reducing bacterium isolated from an upflow anaerobic sludge blanket (UASB) reactor treating cheese wastewaters. Anaerobe 6, 305312.

Hungate, R. E. (1969). A roll tube method for cultivation of strict anaerobes. Methods Microbiol 3B, 117-132.
Jukes, T. H. \& Cantor, C. R. (1969). Evolution of protein molecules. In Mammalian Protein Metabolism, vol. 3, pp. 21-132. Edited by H. N. Munro. New York: Academic Press.

Kado, C. I. \& Liu, S. T. (1981). Rapid procedure for detection and isolation of large and small plasmids. J Bacteriol 145, 1365-1373.

Kates, M. (1986). Influence of salt concentration on the membrane lipids of halophilic bacteria. FEMS Microbiol Rev 39, 95-101.

Lefèvre, C. T., Bernadac, A., Yu-Zhang, K., Pradel, N. \& Wu, L. F. (2009). Isolation and characterization of a magnetotactic bacterial culture from the Mediterranean Sea. Environ Microbiol 11, 16461657.

Mesbah, M., Premachandran, U. \& Whitman, W. B. (1989). Precise measurement of the $\mathrm{G}+\mathrm{C}$ content of deoxyribonucleic acid by high-performance liquid chromatography. Int J Syst Bacteriol 39, 159167.

Nilsson, T. \& Björdal, C. G. (2008). Culturing wood-degrading erosion bacteria. Int Biodeter Biodegrad 61, 3-10.

Ollivier, B. \& Guyot, F. (2009). Sulfate-reducing bacteria: a deep biosphere-early life connection? Environ Microbiol Reports 1, 14-16.

Ollivier, B., Cayol, J. L. \& Fauque, G. (2007). Sulphate-reducing bacteria from oil fields environments and deep-sea hydrothermal vents. In Sulphate-Reducing Bacteria: Environmental and Engineered Systems, pp. 305-328. Edited by L. L. Barton \& W. A. Hamilton. London: Cambridge University Press.

Palacios, C., Zbinden, M., Pailleret, M., Gaill, F. \& Lebaron, P. (2009). Highly similar prokaryotic communities of sunken wood at shallow and deep-sea sites across the oceans. Microb Ecol 58, 737-752.

Parkes, R. J. \& Sass, H. (2007). The sub-seafloor biosphere and sulphate-reducing prokaryotes: their presence and significance. In Sulphate-Reducing Bacteria: Environmental and Engineered Systems, pp. 329-358. Edited by L. L. Barton \& W. A. Hamilton. London: Cambridge University Press.

Saitou, N. \& Nei, M. (1987). The neighbor-joining method: a new method for reconstructing phylogenetic trees. Mol Biol Evol 4, 406425.

Simonato, F., Campanaro, S., Lauro, F. M., Vezzi, A., D’Angelo, M., Vitulo, N., Valle, G. \& Bartlett, D. H. (2006). Piezophilic adaptation: a genomic point of view. J Biotechnol 126, 11-25.

Tamburini, C., Goutx, M., Guigue, C., Garel, M., Lefèvre, D., Charrière, B., Sempéré, R., Pepa, S., Peterson, M. L. \& Wakeham, S. (2009). Effects of hydrostatic pressure on microbial alteration of sinking fecal pellets. Deep Sea Res Part II Top Stud Oceanogr 56, 15331546.

Vainshtein, M. B., Hippe, H. \& Kroppenstedt, R. M. (1992). Cellular fatty acid composition of Desulfovibrio species and its use in classification of sulfate-reducing bacteria. Syst Appl Microbiol 15, $554-566$.

Widdel, F. \& Pfenning, N. (1984). Studies on dissimilatory sulphatereducing bacteria that decompose fatty acids. Isolation of a new sulfate-reducing bacteria enriched with acetate from saline environments. Description of Desulfobacter postgatei gen. nov., sp nov. Arch Microbiol 129, 395-400.

Winker, S. \& Woese, C. R. (1991). A definition of the domains Archaea, Bacteria and Eucarya in terms of small subunit ribosomal RNA characteristics. Syst Appl Microbiol 14, 305-310.

Yano, Y., Nakayama, A., Ishihara, K. \& Saito, H. (1998). Adaptive changes in membrane lipids of barophilic bacteria in response to changes in growth pressure. Appl Environ Microbiol 64, 479-485. 